OPEN ACCESS

Edited by:

Leah Sprain,

University of Colorado Boulder,

United States

Reviewed by:

Richard Buttny,

Syracuse University, United States Kenneth Walker,

University of San Antonio,

United States

*Correspondence: Jen Schneider

jenschneider@boisestate.edu

Specialty section:

This article was submitted to Science and Environmental Communication,

a section of the journal

Frontiers in Communication

Received: 13 November 2017 Accepted: 15 January 2018

Published: 06 February 2018

Citation:

Schneider $J$ and Peeples J (2018) The Energy Covenant: Energy Dominance and the Rhetoric of the Aggrieved.

Front. Commun. 3:5.

doi: $10.3389 /$ fcomm.2018.00005

\section{The Energy Covenant: Energy Dominance and the Rhetoric of the Aggrieved}

\author{
Jen Schneider ${ }^{1 *}$ and Jennifer Peeples ${ }^{2}$ \\ 'School of Public Service, Boise State University, Boise, ID, United States, ${ }^{2}$ Department of Languages, Philosophy, \\ and Communication Studies, Utah State University, Logan, UT, United States
}

The Trump Administration has adopted "energy dominance" as its guiding ideology for energy policy, marking a notable shift from decades of "energy security" rhetoric. This paper analyzes how Secretary of Interior Ryan Zinke, one of the administration's key spokespeople for energy dominance, uses "energy covenant renewal" to frame the importance of energy dominance for the conservative base. Covenant renewal is a modified form of the jeremiad; Zinke uses it to unite conservative identities around energy politics and policies. Energy dominance thus invites those who feel aggrieved under Obama administration regulatory policy and the multicultural identity politics of the left to renew their commitment to fossil fuels, American exceptionalism, and a restored social order and privilege.

Keywords: energy dominance, jeremiad, covenant renewal, energy communication, energy democracy, energy policy, environmental rhetoric

\section{INTRODUCTION}

On September 29, 2017, Secretary of the Interior, Ryan Zinke, was hosted by the conservative organization the Heritage Foundation, where he gave his first major policy address titled: "A Vision for American Energy Dominance." In this speech, Zinke outlines a vision for how the Department of the Interior (DOI) can aid in reversing decades of "American energy dependence." The speech received media attention for how Zinke began it-he provided a lengthy defense of his own use of non-commercial flights, relevant because Health and Human Services Secretary Tom Price had just been ousted from the Trump Administration for the same action (Adragna, 2017). What received less popular attention, however, and what is especially important about the speech, was its substance: Zinke's explication of the Trump administration's new approach to energy policy, known as "energy dominance." We focus on that substance in this paper.

We examine this speech because it is one of the more complete statements addressing energy policy to have emerged from the often-chaotic messaging apparatus of the first-year Trump administration. It also comes from one of its key spokespeople. Zinke, along with Scott Pruitt, administrator of the Environmental Protection Agency, and Rick Perry, Secretary of the Department of Energy, are the primary mouthpieces for "energy dominance." We use rhetorical analysis to demonstrate that energy dominance not only draws on previous, familiar energy and political discourses but also departs from them in ways that have significance for how conservative identity politics are playing out in this political moment. This analysis is therefore in conversation with other types of energy communication work that focuses on how legacy energy systems resist change, consolidate power, and construct identity (see Endres et al., 2016). 
In trying to define "energy dominance," the Zinke speech covers a lot of complicated territory, chaotically jumping from domestic to international policy, making unexplained and unsupported claims about jobs and energy markets, and offering contradictory visions of regulation. It attempts to mark how energy dominance differs from "energy security" (or its close cousin, "energy independence") - the reigning energy discourse of the twentieth and twenty-first centuries (Tidwell and Smith, 2015). It not only carves out a significant and increasing role for the DOI in setting national energy policy but also makes claims about foreign policy more suited to the State Department than Interior: Zinke argues that America is both one of the greatest nations on earth and the most under siege by foreign players who have attempted to manipulate the United States, such as through the Iran nuclear deal. Zinke also calls for an immediate and total reversal of Obama-era environmental and energy regulation, while at the same time noting that the United State's regulatory apparatus makes the nation superior to other unregulated places such as Africa and the Middle East. President Trump's campaign slogans are interwoven throughout. His voice wavering with emotion, Zinke states: "It is time to stop the bleeding. It is time to put America first. Under President Trump, American energy, mined and produced by American hands, will make America great again" (Zinke, 2017).

Given this mishmash of messages and slogans, those looking to understand the administration's approach to energy policy can be forgiven for feeling baffled. Statements from Trump's White House (The White House, 2017) have not helped to clarify things, either. Journalist Liam Denning (2017) confesses: "I am perplexed by the 'Energy Dominance' slogan the White House has adopted. It isn't entirely clear to me who or what is being dominated and whether that's even a desirable thing" (Denning, 2017). Bordoff (2017), writing for Foreign Affairs, argues that the term is "unfortunate" at best and meaningless and uninformed at worst. He and others note that energy dominance arguments do not match policy realities. Energy dominance avoids the fact that the United States remains one of the largest net importers of petroleum products worldwide and that its petroleum reserves pale when compared with those of other oil-rich countries, making achieving "dominance" difficult; energy markets are global in nature, making isolation challenging if not impossible to achieve; and the Trump administration has proposed cutting funding for a number of energy research and development projects, which it has paradoxically pointed to as evidence of innovation and growth (Bordoff, 2017; Mufson and Mooney, 2017). As another journalist put it: “...even if it were desirable, dominance of global energy markets in today's world is simply unrealistic. There is no Roger Federer of energy" (Raimi, 2017).

From a policy perspective, therefore, the connections Zinke draws seem at times non-sensical, disconnected from policy realities, statistics, and the dictates of the market. But we argue that those looking for policy direction from Zinke are paying attention to the wrong things. The speech makes little effort to construct rational arguments or reference data related to energy policy and to assess it as such misses the larger point. The intention of the speech, we argue, is to connect energy dominance to other narratives of grievance for its intended audience-alienated American conservatives. Energy dominance relies on "an affective economy driven by invested identities and entrenched political projects that are dominated by white public feelings of fear, anger, anxiety, and vengeance" (King, 2017a). It thus functions as a moral call-to-arms for conservatives to come out from the trials under which they had been tested during the Obama administration, drawing on discourses of American exceptionalism, militarism, and gender, race, and class resentment and grievance.

We make this argument based on our analysis of the speech as a "covenant renewal" - a charge to the chosen ones who have suffered at the hands of evil others, but who can regain their prominence if they again commit to the covenant laid out by the speaker (Bostdorff, 2003). As support, we first introduce the jeremiad narrative structure and its lesser-known relative, the covenant renewal. Second, we explain the factors within United States politics and society that have created an environment ripe for Zinke's rhetoric. We then examine Zinke's address through the narrative structure of the energy covenant renewal. In it, Zinke's persona is that of prophet; a prophet constructed using the iconography of white American masculinity and therefore aligned with the suffering chosen people. His emphasis on renewing the energy covenant speaks to the aggrieved-a shift away from the traditional jeremiad, which usually focuses on redeeming the fallen. The aggrieved in this case are those on the far right who feel they have suffered under and been disadvantaged by decades of economic disenfranchisement, most commonly expressed through racial animus (Coates, 2017; King, 2017a; Rubin, 2017). Finally, Zinke uses the energy covenant renewal to offer a "golden era" for the conservative right, premised on "energy dominance," the undoing of Obama-era policies, and a refiguring of traditional social order resonant with the discourses of contemporary conservative identity politics. We conclude by arguing that the Puritan covenant renewal, a timeworn form, thus regains contemporary salience under extreme partisanship, populism, and in response to countermovements on the left, including energy democracy.

\section{ENERGY COVENANT RENEWAL}

Covenant renewal as a rhetorical device is an adaptation of the traditional jeremiad. The jeremiad is a Puritan lament intended to warn those blessed by God that they are falling into sin and must work to regain their virtue. It has four key elements: "(1) a chosen people has failed to keep covenant with key values or principles, (2) the people will suffer calamity as a result of this misbehavior, (3) such calamity will be avoided by a return to specified righteous action, and (4) through proper action the chosen people shall recapture their favored status and avoid ruin" (Salvador and Norton, 2011). The jeremiad narrative structure has proven its flexibility and staying power, as it has been applied to contemporary protest, political, presidential, and neoliberal discourses, each with a distinctively American variant. Murphy (1990) explains:

[The rhetors] assume that Americans are a chosen people with the special mission of establishing that 'shining city on a hill.' They point to the difficulties of the day as evidence that the people have failed to adhere to the 
values that made them special, to the great principles articulated by patriots such as Jefferson and Lincoln. The evils demonstrate the need to renew the American covenant and to restore the principles of the past so that the promised bright future can become a reality. (Murphy, 1990, p. 403)

In addition to political and presidential address, the jeremiad has been employed in environmental rhetoric (Opie and Elliot, 1996): Dr. Seuss's The Lorax (Wolfe, 2008), Al Gore's documentary An Inconvenient Truth (Rosteck and Frentz, 2009), the environmental apocalyptic movie The Day After Tomorrow (Salvador and Norton, 2011), Reverend Billy's environmental discourse (Kaylor, 2013), and Thomas Friedman's “Code Green” (Singer, 2010). The jeremiad's frequent invocation in environmental discourse works to persuade audiences that while they have been given a healthy, sustaining environment, their behavior (overconsumption, pollution, and greed) has created a calamity that can only be rectified by humans changing their ways. Opie and Elliot (1996) concluded that the environmental jeremiad will continue to be expressed because "it is the best device for handling the most difficult subject-the representation of American people in their environment" (p. 35).

While maintaining many of the aspects of the jeremiad, we argue that Zinke's energy dominance address can more accurately be described as using the narrative structure of the "covenant renewal." The covenant renewal, Bostdorff (2003) explains, is a variation on the jeremiad crafted for the second and third generations of Americans who were beginning to question and leave the Puritan faith. Leaders knew they needed to revitalize the church. The jeremiadic approach of blaming parishioners for their "failings" and demanding hard work as a path to redemption was deemed ineffectual as a method for bringing young people back to the church. Bostdorff writes: "Although ministers still criticized untoward behavior in their congregants, their rhetoric began to concentrate more on external enemies like the English, the Indians, and Satan and his witches.... Through this external focus, younger generations were able to escape the full burden of blame for the state of New England's covenant" (p. 295). Instead of using the fear of moral failure as motivation for the congregation to remain active in their faith and good works, the ministers pointed to the crises as "tests from God that the community had successfully passed (rather than as evidence that the community had strayed)" (Bostdorff, 2003, p, 297).

Following the narrative structure of the covenant renewal, Zinke's energy dominance rhetoric constructs an energy covenant renewal. He establishes himself as prophet with a clear and unquestioned vision of America's values, strengths, and failures. Zinke addresses the "chosen people" of the Heritage Foundation and those audience members who he implies had been tested during the Obama years (e.g., American men, patriots, main street residents, and the working class). He characterizes them as having done little to deserve their hardships. With a renewed investiture and belief in the broadly neoliberal energy covenant, however, they will again be dominant in the world.

It is important to note that jeremiads and covenant renewals are frequently employed to speak to or unite a singular American people (Sillars, 1980; Murphy, 1990; Bostdorff, 2003). Analyzing President Bush's speech after September 11, Bostdorff (2003) explains how the president used the renewal discourse to "place blame for September 11 on evil, external enemies and to cast the U.S. and its citizens as a blameless, exceptional community that had been attacked because of its goodness" (pp. 298-299). As this example illustrates, the jeremiad and renewal narratives often use polarizing discourses - the blessed and the sinners, the good and the evil, the righteous and the fallen. These variants typically unify Americans as the chosen people. In direct contrast, Zinke's speech suggests that some Americans are chosen, specifically those conservatives who found themselves tested during the Obama years. Those who are not chosen, a distinction formally reserved for foreign threats, are the Americans who did not follow the energy covenant, who supported the Obama administration and energy democracy activists, and who advocated against fossil fuels.

\section{THE AGGRIEVED}

Concerns about energy security and independence have not disappeared under the Trump Administration, but they are augmented by a sense of victimhood and "grievance" under energy dominance discourse, which promises restoration. Energy dominance borrows from security and independence rhetoric in that it still underwrites American energy privilege, justifies foreign and domestic energy policies using American exceptionalism, and relies on "sacrifice zones" (see Endres, 2009; de Onis, 2017). Early in the speech, Zinke states this explicitly:

Our goal is an America that is the strongest energy superpower this world has ever known. Our country has inherited an energy dependent country from previous generations. And in recent years, we've struggled to be self-sufficient in producing low-cost, abundant, and reliable energy. But a new era is dawning. With American leadership, innovation, and good ideas, our challenge will be to pass energy dominance onto our children and grandchildren. (Zinke, 2017)

Here, we see some of the themes of energy independence repeated-Zinke's call for the United States to become self-reliant and insulated from global energy markets.

However, energy dominance is different from energy independence in that it specifically frames energy access as a right of some Americans, who are authorized to become "dominant." Such calls emerge at a time when American politics and identifications are deeply polarized, with the conservative base being mobilized by rhetoric that acknowledges their grievances. "Dominance" rhetorics speak to and for those on the right who have felt wronged by a perceived loss of power, influence, and privilege as a result of demographic and political changes that have taken place during the last few decades, seemingly exacerbated by the Obama administration (López, 2015; King, 2017a). Energy dominance discourses are thus best understood as a manifestation and articulation of these politics of grievance, which become more apparent when analyzed through the lens of the energy covenant renewal. 
The themes of Zinke's discourse-victimhood, exceptionalism, and renewal-are especially powerful and present in conservative political discourse under the Trump Administration, as can be seen most clearly in the increasing visibility and influence of the alt-right (Alternative Right, 2017; Dimaggio, 2017). Mike King (2017a) persuasively argues that white victimhood is a prominent form of identification not just for the alt-right but in contemporary conservative politics writ large. With grievance appeals, the facts of victimhood are irrelevant. It does not matter that coal has suffered more from competition with cheap natural gas than from environmental regulation, just as it does not seem to matter that, in material terms, white Americans do not suffer the same systematic discrimination that people of color do, or that straight men do not suffer under gender discrimination and heteronormativity like women or those who identify as LGBTQ. King writes:

the political identity of 'victim' has become decoupled from a materialist analysis (across the political spectrum). In this context, dominant groups (whites, men, heterosexuals) have adopted identity politics and posited themselves as victims - of affirmative action, of political correctness, of diversity, and of social programs that purportedly serve to advance the social standing of nonwhite, nonmale, non-Christian, nonheterosexual persons. [...] the (often perceived) lost privileges of dominant groups has been formulated as a moralistic political grievance, and translated into this language and affective economy of victimized identities. (King, 2017b)

Such narratives, like the energy covenant renewal, function on the level of symbolism and affect and give voice to feelings on the conservative right that something has been lost and must be regained.

\section{ZINKE AS PROPHET}

Secretary Ryan Zinke has been zealous when it comes to defending fossil fuels and articulating energy dominance policies and ideology. The DOI is responsible for overseeing the production of energy on public lands, including through the Bureau of Land Management, National Parks Service, and the Bureau of Ocean Energy Management. Zinke has worked swiftly and effectively to reverse the "keep it in the ground" policies of the Obama administration and increase oil and gas leasing on public lands (Lipton and Meier, 2017), to expand offshore drilling operations (U.S. Department of the Interior, 2017e) and to open up formerly protected spaces such as the Alaskan National Wildlife Refuge to oil and gas companies (U.S. Department of the Interior, 2017b).

Zinke has earned a reputation for paying lip service to an "all of the above" energy strategy, which ostensibly includes both fossil fuels and renewables-he is fond of saying: "This administration does not pick winners and losers” (e.g., Backus, 2017; Grandoni, 2017; Zinke, 2017). However, his actions suggest a strong preference for fossil fuels. His record as a former Montana congressman reveals a commitment to defending fossil fuel interests, and while a United States Representative, he received significant campaign donations from those industries (Lipton and Meier, 2017). Furthermore, like EPA administrator Scott Pruitt, Zinke has so far systematically excluded environmental groups and renewable energy advocates from his stakeholder interactions, while embracing fossil fuel interests (D’Angelo, 2017b; Hiar, 2017). In his speech and during public appearances, Zinke claims to care deeply about public lands and environmental conservation: "Nobody loves our public lands more than I" (Zinke, 2017). However, given his funding track record, his privileging of fossil fuel interests through meetings and speeches, and his willingness to open up public lands to drilling, he is clearly emerging as a fossil fuel advocate and not a supporter of "all-of-the-above" energy policies. In his speeches, he articulates that protection of public lands is synonymous with fossil fuel development:

We're going to probably be, this year, number one in oil and gas. And next year, we will likely be a net exporter in liquid natural gas. That's the first time in sixty years. And our nation will continue, I am convinced, to increase market share, and we have a great opportunity to fuel the world. And stewardship of our public lands, I take seriously.... Energy development and hunting and fishing and camping and habitat and protection and other forms outdoor recreation are all part of conservation. (Zinke, 2017)

Through this speech and others, Zinke has thus emerged as perhaps the most visible and vocal spokesperson for energy dominance in the Trump administration, other than Trump himself (see Woods, 2017). On these grounds, we argue that Zinke serves as prophet for the energy covenant renewal.

As a prophet upholding the American energy covenant, Zinke demands allegiance and punishes those who oppose his views, calling them out for not being "loyal to the flag" (Fears and Eilperin, 2017). Furthermore, under Zinke's leadership, the agency now has a reputation for not "tolerating dissent" (Shogren, 2017) - a consolidation of the prophet's influence and voice. In his 2017 speech, Zinke articulates a top-down vision of management wherein multiple federal agencies learn to "work together," but he emphasizes a command-and-control organizational structure: "This is how we fight fires in the west, and this is how the military does it, so this is nothing new. It's straightforward, and that is how we are going to get to 'yes"' (Zinke, 2017). He shows his displeasure with what he calls political "B.S." and the mishandling of American wealth by the Obama administration (Zinke, 2017; Soundcloud, 2017a). Zinke has eagerly stepped into some of the most fraught contemporary political debates, engaging with the press on issues ranging from the role of confederate monuments in national parks (Al-Sibai, 2017) to the use of private jets for professional travel (Zinke, 2017).

Zinke as prophet is able to reiterate and amplify Trump administration talking points, often making them seem more palatable and politic than the administration can itself. Capturing this sentiment, journalist Woods titled his profile of Zinke "Ryan Zinke is Trump's attack dog on the environment" (2017). The persona he constructs for this position is a strongman, one that he 
bolsters with his frequent references to his biography as a former Navy SEAL. In his searing profile of Zinke published in Outdoor Magazine, Woods (2017) notes: "Zinke’s SEAL credentials have given him enormous cachet, which he has used throughout his political career. The trident appeared on his campaign bus when he ran for Congress in 2014, he continues to wear a small trident on his lapel, and he rarely fails to mention his service in speaking arrangements." Woods goes on to note that Zinke has been accused of misrepresenting his service by suggesting he was part of the SEAL team that assassinated Osama Bin Laden; such misrepresentations and slight manipulations of the truth continue to dog Zinke's actions as Secretary, though he dismisses them out of hand (e.g., Rein and Harwell, 2017).

Zinke tempers his military persona by playing the part of the down-home, salt-of-the-earth Montanan-a beer-drinking, joke-making "guy's guy"-a man of the people (Plott, 2017). For example, in August 2017, Zinke was accused of trying to strong-arm Alaska Senator Lisa Murkowski over her vote against Republican-led health care reform; she allegedly responded by threatening to slow-walk the congressional confirmation of some of his DOI appointees. The two privately reached a detente, and the dustup was smoothed over publicly when Zinke tweeted a picture of himself and Murkowski sharing a beer with the message, "I say dinner, she says brews. My friends know me well" (Beavers, 2017). Cultivating this down-home approachability and authenticity, Zinke also opted for a horse as his means of transportation on the first day of the job as a nod to his bona fides as a Montanan and to his new position at Interior overseeing vast public lands, including ranchlands. Finally, bolstering this horse riding, militaristic persona, Zinke declared on Twitter and Facebook that he was a "Teddy Roosevelt fan," though critics have countered that Zinke so far is "all Roosevelt hat and no Roosevelt action" (Freemuth, 2017).

In addition to speaking for a larger, more powerful entity, a prophet is also given the ability to unerringly see right and wrong, good and evil, with a clarity not even bestowed on "the chosen people." Zinke uses (his experiences) in the military and as a Westerner to provide credibility for this infallible vision. For example, in a somewhat rambling, perhaps extemporaneous section of the speech, Zinke links together concerns for the environment globally with national security concerns-including nuclear proliferation in Iran-with calls to deregulate and innovate in order to save small-town, local economies that are suffering. In the speech he states: "As a former military commander [I can say that] Iran is a grave threat [...] being able to supplant every drop of crude that Iran produces, is a leverage, and energy dominance is part of that" (Zinke, 2017). He goes on: "American prosperity...jobs matter. Hardworking Americans deserve to have a future, and they deserve to have an opportunity to obtain the American Dream" (Zinke, 2017). Zinke then goes on to reference the suffering in his home state of Montana: "Out West, local communities like my home state of Montana, you know... sincere hurt. And I come from a railroad and timber town. If you want to see small towns get stripped, no jobs, the elderly, kids cannot come home, it affects a lot of small communities" (Zinke, 2017).

Finally, the most notable characteristic of the prophet is the prophet's unassailable ability to see and speak the greater truth.
True to form, Zinke relies on positioning himself as a clear-eyed realist to justify energy dominance policies. When announcing an Executive Order that would review oil and gas leasing practices on public lands, Zinke claimed: "Our nation can't run on pixie dust and hope. And the last eight years showed that" (U.S. Department of the Interior, 2017c). Similarly, when commenting on DOI's move to make drilling permits for federal lands easier to obtain, Zinke noted: "We're going to be a fair and prudent partner, but we're not going to be an adversary to creating wealth and opportunity on some of our public lands" (quoted in The Associated Press, 2017). Realist rhetoric is difficult to counter, because it places the critic in the position of being "unrealistic" or extreme (Peeples et al., 2014). The fossil fuel industry and its allies are particularly adept at employing the realist rhetoric of moderation, of common sense, and of "the center" so that environmental challenges are positioned as ideologically motivated, unrealistic, and even absurd (Schneider et al., 2016), a tactic used by Zinke as he details the ways certain Americans have fallen away from the values he argues had made America great before the Obama administration.

\section{OBAMA AND THE VICTIMHOOD OF THE CHOSEN}

In the energy covenant renewal, the prophet calls on those who have been injured and victimized-who see themselves as the chosen, but suffering-to sign on to a covenant that will renew their eminence. Just as coal, for example, has suffered under the environmental regulation of the Obama era, so too have the white middle and working classes suffered under failed economic policies and the culture wars. The emphasis of Zinke's energy covenant renewal is on what has been lost during the backward, lost years of the Obama administration, and on how to reverse that damage for the chosen.

In the classic version of the jeremiad, the people have fallen from grace and must be redeemed; the energy covenant renewal deviates from this traditional form in that, while the people are still "favored" or "blessed," they did not fall out of favor because of their own actions, but because they were victimized by the liberal elite. They may have been duped by multiculturalism and political correctness into wavering from conservative values, but they will not be fooled again: Zinke uses the renewal narrative to emphasize the stark differences between the values and policies of the far left and the far right and to frame their actions under Trump as restoring moral and economic order. Familiar conservative arguments addressing deregulation and jobs are matched with covenant and restoration language that suggests energy dominance will guide the victimized out of the wilderness to which they have been cast, and to regain their elevated position.

Undoing the Obama agenda becomes of utmost importance under the terms of renewing the neoliberal covenant. Obamaera policies and rhetoric led to conservatives feeling aggrieved. The Obama administration enacted a number of regulations, particularly in its second term and especially aimed at coal, that have become symbolic targets under the Trump administration (e.g., Burnett, 2017; Federman, 2017). Zinke takes aim at the 
Obama regulatory agenda in his energy dominance speech, separating the good Americans from the enemies. From the start, he positions American energy politics as made of up "two sides." He argues that one "vision for the future" of US energy "believes we should retreat into a fortress of regulation and red tape, where foreign nations take the lead while America drowns itself in process and procedure. This is not the vision of President Trump" (Zinke, 2017). Though he does not state it explicitly, the straw man "vision" here clearly refers to Obama-era rule-making and regulation.

Zinke lays out the ways that the chosen Americans were tested under the Obama administration:

(1) Too much environmental regulation, which was ideologically motivated and which unfairly targeted fossil fuels. Zinke calls out the Obama administration for purposely slow-walking permits-ostensibly for drilling and pipelines_-and declares: "Regulations should be grounded on [sic] science and careful analysis and not agenda and ideology. That is why this administration is reducing punitive regulations that have stagnated our economy, and we are cutting the regulatory agenda by over $50 \%$. This is a national imperative" (Zinke, 2017). Zinke positions Obama-era policies as unfairly punishing and biased against fossil fuels-Obama clearly "picked winners and losers"-while Trump-era Energy Dominance will remove government interference and allow markets to return to their natural state.

(2) Attack on the free market. The previous administration handicapped economic growth for fossil fuels, especially, and market realism demands that fossil fuel production should be allowed to proceed unfettered. In the speech, Zinke complains that the National Park Service is both underfunded and understaffed and that the solution is to re-energize fossil fuel development in order to replenish DOI coffers. For Zinke, the challenges he faces as Secretary have been made substantially worse, not by falling oil prices, but by Obama-era regulations: "That's the consequence of putting $94 \%$ of our offshore holdings off-limits, and even making the National Petroleum Reserve unavailable for exploration and development" (Zinke, 2017). Partnerships with fossil fuel industries are the solution for lack of national park funding. Restoring free markets-but paradoxically, only for fossil fuels-will right much of what ails the federal bureaucracy.

(3) The working and middle classes have suffered as fossil fuels have suffered. The regulatory attack on fossil fuels has also been an attack on "Main Street." Obama-era policies, Zinke argues, were particularly harmful to the working and middle classes. Under Obama's policies, "local economies suffer, as the focus on bureaucracy over prosperity delayed jobs and prevented wealth that American energy promised to bring" (Zinke, 2017). Here, the Obama administration, allied with mainstream environmentalism and social protest, is portrayed as purposefully preventing some communities from developing wealth. Zinke argues that "hard-working men and women" and "local businesses and opportunities" have suffered under "moratoriums and bans." "Trillions of dollars in American wealth and millions of jobs have been moved overseas as our politicians here at home have turned their back on America's potential for energy dominance" (Zinke, 2017).

Such grievances must be righted by an aggressive, Americafirst energy covenant. Pointing to Alaska as a prime example, Zinke holds up the state as being on the "road to energy dominance," which means more fossil fuel development and therefore self-determination. "The last administration turned their back on these patriotic and enormously proud people. I can tell you...they have the right to make their own decisions" (Zinke, 2017). This claim echoes that Trump Administration grievance appeals more broadly, which according to King (2017a) are about the righting of grievance and the restoration of privilege: "The dominant slogan of the Tea Party movement of 'Taking Back our Country' or the resonance of Donald Trump's 'Make America Great Again' speak directly and plainly to this widespread sentiment that white people are losing political control and economic standing within a polity where social dominance is implicitly their birthright."

The "higher purpose" of energy dominance as articulated by Zinke in the speech is that its policies and motivations offer the clearest path out of the disastrous Obama years, typified by overwrought concerns with social justice, deregulation, and the hamstringing of the middle and working class American. Energy Dominance will redress suffering, restore the middle-class self under fossil-fuel-dominated markets, and right a social order upset by meddling bureaucracies and activists. In the next section, we turn to how energy dominance offers a means of restoring prominence to the aggrieved.

\section{ENERGY DOMINANCE AND THE PROMISE OF THE NEOLIBERAL COVENANT}

The redemptive power of energy dominance lies in appeals to restore social order, justified through the exceptionalism of chosen Americans, who if they again renew their covenant with the values of neoliberalism will raise America to a position of superiority with unrestrained expressions of global power. Here, we examine each element in turn.

\section{American Exceptionalism and Social Order Restored}

"Energy dominance" is a nod to the web of identities, meanings, and symbols fossil fuel industries have built up around their products; in particular, American energy has been synonymized with a neoconservative "American identity," one that is primarily working- or middle-class, heterosexual, and white (Bsumek et al., 2014). Access to affordable, reliable energy, and to well-paying jobs in the energy industry, have been key elements of "energy privilege," which has clear social, race, and gender dimensions (Scott, 2010; de Onis, 2017). When American energy fails to be "dominant," so too do groups accustomed to dominance. According to Mike King, "A consistent feature of the United States racial order has been the intrinsic elevation of all whites 
- regardless of occupation, education, wealth, or personal lifestyle-to a socio-political status higher than other racial groups" (King, 2017a). Loss of privilege signifies a loss in status and a social order out of place.

The energy covenant renewal therefore promises to reverse perceived declines in energy privilege and to restore social order by bolstering markets that privilege fossil fuels. Zinke's strongman appeal as prophet, his promises to reassert American energy hegemony, and his guarantees to return jobs and profits to those who have lost out under Obama come together to articulate a nostalgic, redemptive path to greatness. He promises that "jobs matter" and that the Trump Administration wants to be "fair and transparent with our job-creating energy sector" and to be "a better business partner with industry" (Zinke, 2017). He insists that industry will be held accountable environmentally, but notes that DOI will welcome "responsible development," with innovation as the response to environmental and safety concerns, rather than creating "punitive regulations that have stagnated our economy” (Zinke, 2017). Zinke also implies that while renewable energy sources such as wind and energy have seen some gains, they are not market-competitive with fossil fuels: "...they also have to market-driven and at a cost point where they are competitive.... Until we [sic] are, we have to use the resources we have" (Zinke, 2017). Zinke nods to the importance of market logics here, though without paying attention to actual markets, which have increasingly shown renewables to outperform coal and nuclear in affordable electricity production.

Through deregulation and allowing fossil fuels to flourish again, small town America will be restored to its former greatness. Using coal-dependent West Virginia as an example, Zinke articulates the energy covenant renewal in one clear narrative:

One of the hardest places hit in [sic] the last administration was in West Virginia. Eight months ago, West Virginians [the chosen] had lost hope [but not fallen]. Mines were closing. Jobs were being ripped away [through little fault of their own]. But under this administration, West Virginia is roaring back. We recently celebrated the opening of the Berwind mine, which brought back economic security and hope [the covenant renewed]. And the first quarter of 2017, West Virginia was second in the nation in GDP [the promise of neoliberalism is proven]. (Zinke, 2017, bracketed comments inserted)

Here again, material realities are ignored in favor of a symbolic narrative of decline and renewal. As coal is restored, so too will be the white middle and working classes and their access to economic opportunity. The path to redemption flows through the Trump White House, which will reverse the prior "administration's war on coal and mining and timber and the ability for a local community [to] have opportunity and to use our public lands for wealth" (Zinke, 2017).

As Zinke lays out the means of regaining certain Americans' "chosen" or "exceptional" status, he therefore advocates for increased domestic production of energy. He frames this argument as the "reasonable" approach, as seen with other neoliberal discourses (Singer, 2010; Schneider et al., 2016), evidencing his claims using the prophetic vision that he has gained from being in the military and concludes with America's righteousness. $\mathrm{He}$ claims that other countries have little or no regulation, making their production much less environmentally friendly:

And it's better to produce energy here, under reasonable regulations, than watch it get produced overseas with none. As a Navy SEAL, I've been to a lot of countries in my life. If you want to watch how energy is produced without regulation and the consequences that has, I invite you take a tour with me to the Middle East and Africa. I can assure you America leads the world in innovation and regulation to make sure our energy is done right. Period. We're the model for the world. (Zinke, 2017)

From a policy perspective, the speech therefore contains internal contradictions. On the one hand, Zinke maintains throughout that deregulation is a significant platform of energy dominance. On the other hand, he claims that environmental protection cannot be sacrificed and that the United States' regulatory structure is what ensures that "energy is done right," i.e., that environmental degradation and the loss of public health do not rule the day. $\mathrm{He}$ affirms market logics but ignores market realities. If we shift our analytical lens away from looking for a consistent policy platform and toward the narrative construction of the energy covenant renewal, however, what becomes clear is that Zinke's message is about reaffirming the correctness and dominance-both moral and economic - of America's place in the world and reasserting the flow of wealth to particular communities facing a loss of energy privilege.

\section{An Energy Super Power}

In his speech, Zinke argues that "energy dominance" is different from "energy independence" because it recognizes that "America is exceptional" (Zinke, 2017). "This administration and the President believe in American energy dominance.... Our goal is an America that is the strongest energy superpower this world has ever known" (Zinke, 2017). The extension from American exceptionalism to superpower undergirds a key aspect of the energy covenant renewal, which is the promise that exerting strength will protect the chosen from ever feeling victimized again. In the speech Zinke states: "Going forward, our participation in the global energy market will protect and defend American sovereignty, not surrender it" (Zinke, 2017). He continues: "Under President Trump, we will put America first, and we will put America's energy first" (Zinke, 2017).

Energy security rhetoric historically reinforced promises to Americans that they would be insulated from the vagaries of international energy markets, especially following the oil shocks of the 1970s, which resulted in fuel shortages and long lines at gas stations (Mattson, 2009). But whereas energy security promised to protect Americans from such shocks through protectionism, energy dominance promises protection through aggressive movement into global markets while refusing to cede any ground 
through international agreements, such as the Iran nuclear deal or the Paris Climate accords. Energy dominance thus posits that the United States should be insulated from vulnerability and American military interventions abroad, but that the country should have unfettered access to and dominance of "global markets," without paying the cost of externalities, such as climate change.

Zinke argues that becoming energy dominant will ensure that the United States is energy secure and will "never be held hostage to a foreign country to heat our homes and to power this nation" (Zinke, 2017). His voice breaking with emotion, Zinke goes on to "speak personally" about his experiences in the military, the weight of his position as Interior secretary and the "America First" vision of the Trump Administration. He implores: "I don't want to ever see your children have to fight overseas for a commodity we have here. I've been to battle, and I never want your children to see what I've seen" (Zinke, 2017). Though he does not mention them by name, Zinke appears to be referencing prolonged conflicts in Iraq and Afghanistan, made worse by Obama's inability to withdraw American troops from there. Energy dominance is therefore not really a "globalist" strategy, involving partnerships and multilateral agreements-instead, it imagines a dominance wherein the United States hard-charges into foreign markets, reaping significant benefits but bearing few risks.

\section{IMPLICATIONS}

In this section, we identify four political realities that inform and resonate with energy dominance rhetoric, as it is expressed through the energy covenant renewal: the threat of energy coloniality, political polarization, the rise of populism, and the challenges posed to the status quo by energy democracy.

\section{Energy Coloniality}

Energy policy in the United States-and all of the practices it has enabled and entailed-has historically depended on the following: the construction of a superior, exceptional American state, undergirded by cheap and reliable energy, and created at the expense of expendable "sacrifice zones" and/or colonized peoples. Scholars of energy studies have studied how American energy extraction and consumption practices impact communities, groups of people, and environments differentially, and how those communities organize to resist (Pezzullo, 2009; Mitchell, 2013; Heffron et al., 2015; Endres et al., 2016; Fuller and McCauley, 2016; Reinig and Sprain, 2016). The industrial era and the booming postwar American economy may have been enabled by access to "cheap and plentiful" forms of energy, but that energy was often produced at the expense of poor communities and communities of color, both in the United States and abroad, through the construction of environmental and social "sacrifice zones" (e.g., Kuletz, 1998; Fox, 1999; O’Rourke and Connolly, 2003; Lerner, 2010; Hecht, 2012). de Onis (2017) terms these relationships of planned dependence and exploitation "energy coloniality," which "connects energy with patterns of coloniality, to foreground its use as a metaphor of frequently invoked power relations and also as a resource that often undergirds colonial desires to invade, exploit, and export" (pp. 6-7; see also Endres,
2009). Under this definition, communities and environments that have suffered injustices because of energy production and consumption practices do not have to have been "colonies" in the historical sense to experience energy coloniality.

Like other grievance discourses, energy covenant renewal takes up the mantle of victimhood as justification for deregulation in the domain of energy policy. It recasts the history of energy coloniality - which has always relied on the dominance of marginalized or disenfranchised people, often people of coloras a history in which white Americans have been discriminated against and deserve recompense (King, 2017a). Zinke's calls to re-elevate those who believe they have suffered under Obama's energy and environmental policies are thus meant to resonate with those already feeling aggrieved by demographic and economic shifts. "Energy dominance" on its surface seems to not be about identity politics, but through the energy covenant renewal and its many "dog whistles" may resonate with other rhetorics of dominance that are particularly influential in the age of Trump.

We therefore maintain that the narrative structure of the energy covenant renewal is used to warrant an era of re-energized and explicit energy coloniality. Scholarship on energy coloniality demonstrates that energy production and consumption are related to a whole host of beliefs about national identity and anxieties around masculinity, whiteness, and wealth that have long informed American energy policy (de Onis, 2017). Energy politics and policy cannot be divorced from American politics and policy writ large, and arguments over American identity are often expressed through energy discourses (Jasanoff and Kim, 2013).

\section{Political Polarization}

The energy covenant renewal, as articulated through the rhetoric of energy dominance, is not used to unify the American people, but rather to exacerbate polarization and partisan identity. This marks a notable deviation away from the classic form used to unite Americans in their exceptionalism and highlights a political context typified by polarization. Politicians like Donald Trump face a unique challenge in the United States today-a country marked by pluralism, multiculturalism, a widening gap between rich and poor, and a fragmented media environment. Unlike populists of the past, they will struggle to identify a "people" who can be unified rhetorically. It may also be that Trump and his spokespeople are not particularly interested in unification and that they in fact benefit from polarization. Historian Michael Kazin (2016) argues that the President's rhetoric "lacks a relatively coherent, emotionally rousing description of 'the people' whom Trump claims to represent" (p. 22), but notes that "it has become increasingly difficult for populists-or any other breed of US politician - to define a virtuous majority more precisely or evocatively" (p. 23).

We have argued throughout this essay that the energy covenant renewal does not seek to unify "the people," if by that we mean all Americans. Instead, it exacerbates polarization by pitting the "chosen" on the far right (those who want to see a fossil fuels resurgence) against the liberal elite of the Obama administration (those who privilege environmental regulation). The energy covenant renewal is meant primarily to rouse the Republican base. Zinke speaks through energy dominance to those who have 
felt cast out and aggrieved under 8 years of a liberal, AfricanAmerican President. Grievance appeals unite predominantly white conservative partisans as victims who have lost out under demographic trends, multiculturalism, and political correctness, but who will rise to dominate again. Again, we return to the work of Mike King (2017a), who writes:

This amalgamated white conservatism is central to modern American politics, while its overt racial nature is often subsumed and veiled. Aggrieved whiteness is the coupling of this identity of racially coded politicomoral supremacy (of hard work, responsibility, and meritocratic fairness) within a worldview where this identity has been wronged by entwined forces of social liberalism and racial progress.

We argue that one of the ways conservative partisan identity is solidified is through energy dominance rhetoric, which enables those in power, such as Ryan Zinke, to make promises about restoring social order without explicitly referencing racial politics.

This rhetorical sleight-of-hand is possible because fossil fuels are never just fuel sources. They symbolically stand in for conservative culture and identity-for example, many scholars have noted the layers of significance that surround the meaning of "coal" (Scott, 2010; Bsumek et al., 2014; Schneider et al., 2016). "The coal industry seethes with symbolism," writes journalist Jonathan Thompson (2017):

When Obama was castigated for a so-called war on coal, it was not for trying to mitigate a catastrophic global habit, but for attacking miners, a powerful symbol in rural, white, American culture (85 percent of coal miners are white men, according to the Bureau of Labor Statistics). When Trump demonstrates that he 'digs coal' by rolling back regulations, he's banking on rural nostalgia and pushing back against Obama, who for portions of white America became a symbol of urban elitism, progressivism and blackness.

Attacks on coal-and perhaps on fossil fuels generally-are therefore bound up with attacks on masculinity and on white masculinity in particular. Bringing coal back promises to bring back a lost social order, with Ryan Zinke and Donald Trump leading the way home.

\section{The Rise of Populism}

Donald Trump ran his presidential campaign as a populist, antiestablishment candidate, perhaps best evidenced by his promises to "drain the swamp" and "build the wall." His political rhetoric and communication style follow the "simple, direct, emotional, and frequently indelicate" style of populism (Oliver and Rahn, 2016, p. 191). According to Oliver and Rahn (2016), who argue that Trump's rhetoric is classically populist:

At its core, populism is a type of political rhetoric that pits a virtuous 'people' against nefarious, parasitic elites who seek to undermine the rightful sovereignty of the common folk. [...] Its tone is Manichean, casting politics as a bifurcated struggle between 'the people,' on one hand, and a self-serving governing class undeserving of its advantaged position, on the other. Its goal is restorative, replacing the existing corruption with a political order that puts the people back in their proper place and that is more faithful to their longings and aspirations (p. 190).

Here, we see many echoes of the renewal used by Zinke in his energy dominance speech: the "people" (Zinke's conservative audience) are unified in their suspicions of the ruling class (the Obama administration; large federal government), preferring instead the authentic folk wisdom of the prophet. They also long for order to be restored and challenges to their privilege to be suppressed. We have shown how the energy covenant renewal reinforces these key features of populist rhetoric.

Under Trump, populist rhetoric also has partisan appeal because it resonates with ideological arguments for a vastly reduced federal government (Republican Platform, 2017). Similarly, the focus on critiquing the bureaucracy is another signal that Zinke is delivering a message very much in line with the Trump administration's focus on deregulation and diminishing the "administrative state" by refusing to staff and fund federal agencies, a major priority of the President's former advisor, Steven Bannon (Rucker and Costa, 2017). Although Bannon left the administration in August 2017, several agencies in the federal government remain markedly understaffed compared with previous administrations (Rein, 2017). Zinke negotiates his position as a leader of an administrative agency through the energy covenant renewal, which allows him to argue for resources for DOI via free market solutions and not through taxpayer dollars.

\section{Silencing Energy Democracy}

Privileging industry voices over non-industry voices is a clear hallmark of energy dominance-as we argued above, Zinke uses the renewal to appeal to those who felt they lost clout and privilege during the Obama years. Under Trump, Zinke promises, industry voices will again become dominant. The energy renewal discourses speak primarily to those on the right who perceive they lost out to environmental regulation and who want to see fossil fuels come "roaring back." We argue that energy dominance thus positions itself in direct opposition to energy democracy movements. Those who protest a return to the "Golden Age" and traditional forms of order are not members of the chosen-they are "matter out of place" and need to be dealt with swiftly and decisively. Energy democracy movements, groups, and voices are excluded under the energy covenant renewal. Energy democracy brings together broad coalitions of people to argue for the decentralization of energy systems, decarbonization, collaborative and equitable forms of decision making, and a focus on long-term, intergenerational ethics and sustainability (see Burke and Stephens, 2017). Energy dominance, on the other hand, emphasizes central control, fossil fuels, swift decision making that favors private industry, and short-term profits.

The role of voice is an essential element of energy dominance: fossil fuel advocates are granted voice and access to political 
power, and oppositional voices are silenced. The silencing of protest is therefore an essential piece of returning the United States to its former "greatness." One example from Zinke's speech is illustrative: just moments into the speech, Zinke is interrupted by a woman (off-screen) who asks: "Secretary Zinke, how many calls have you taken...." The rest of her question is inaudible on the video, though journalists later reported that it dealt with the many meetings Zinke has taken with fossil fuel industry leaders (e.g., D’Angelo, 2017b). In response, Zinke leans into the podium and forcefully speaks over the protester, saying: "Our decisions will be guided by our flag, and not kneel to anyone" (Zinke, 2017; italics note inflection in speech).

Zinke's comments here clearly reference the larger cultural debates about the kneeling protests of National Football League players-players who had taken a knee during the playing of the national anthem to protest policy brutality against AfricanAmerican men and who were publically chastised by President Trump and Vice-President Pence as offending members of the military (Bump, 2017). Protest here is framed as un-American and disloyal. Zinke's comment during the speech also echoes his concerns that $30 \%$ of his DOI staff are not, in his words, "loyal to the flag" (The Associated Press, 2017d) and his insistence that a special secretarial flag at DOI headquarters should be flown when he is in the building - a nod to a military tradition (Abrams, 2017). These comments about "flags," "kneeling," and "loyalty" knit together the rhetoric of energy dominance with political identifications in the conservative base that justify the suppression of speech and protest on the left. They underscore the importance of hierarchical forms of order and fundamentally question the role of protest in public life, especially when that protest aims to highlight racial disparity.

Indeed, Zinke's posture toward protesters has not been favorable, and as such echoes conservative critiques of racial or ethnic protest by progressives (Chapman, 2017; Wilson, 2017). During a visit to Bears Ears National Monument in May 2017, Zinke refused to take questions from Cassandra Begay, a woman working as a liaison for Native American tribes involved in the Bears Ears monument designation. A video of their interaction shows Begay asking repeatedly, "When are you going to meet with the tribal leaders?" After she asks the question a third time, Zinke puts his finger in her face and says, forcefully, "Be. Nice. Be nice, don't be rude" (D’Angelo, 2017a). In her interruptions and persistence, Begay was not following the rules of deference and civility, rules that often privilege official, "civil" speech but not indecorous speech or speech from the marginalized (Cloud, 2015).

Similarly, in a moment of irony during the Heritage speech, the woman who interrupted him initially to ask about his fossil fuel connections interrupts again. He continues to speak over her, saying: "As the chief steward of our public lands, my job is to make sure that all Americans have a voice. [Pause]. That all Americans have a voice. And I hear that voice loud and clear" (Zinke, 2017). Zinke does make a nod to local, tribal, and state interests later in the speech, arguing that these groups need to be integrated in decision making to improve "coordination and consultation" (Zinke, 2017). But in practice, Zinke's actions suggest that he is attuned to hearing only one voice-the industry voice-as is evidenced by his enthusiastic embrace of their concerns and rhetoric and his refusal to meet with people from other sectors of American public life as Secretary of Interior. Voices of opposition and protest to fossil fuel hegemony are not voices Zinke is interested in hearing. When he says in the speech, "I can assure you, the war on American energy is over" (Zinke, 2017), the "you" here is addressed to those with stakes in fossil fuel industries specifically. Zinke seeks to silence those who are not "the chosen," rather than bring them into the fold.

\section{CONCLUSION}

In this article, we have maintained that Zinke's discourse highlights a new variant on the American jeremiad and renewal discourses: the American energy covenant renewal. In it a "prophet" or leader establishes a vision of America's values, strengths, and failures. The narrative establishes the chosen Americans, those who have been tested and suffered, but not fallen, by polarizing them from those Americans characterized as undermining the greatness of the country from the inside. A renewed investment in the neoliberal covenant, one that bolsters America through its production of energy, is offered to the chosen as the means for regaining dominance.

While calling for greatness in the future, jeremiad and renewal narratives are always looking to the past, to a previous golden era when the chosen people were not failing or not enduring the suffering of the present. The narratives are therefore fundamentally conservative, attempting to stave off changes that are seen as threatening to the dominant social order, whether they should be religious, demographic, economic, or military. In the United States, neoliberalism is under pressure from large-scale protests such as the Occupy Movement, the strong showing of Bernie Sanders and his transformative economic messages in the last presidential election, and best-selling books such as Naomi Klein's This Changes Everything (Klein, 2014). Fossil fuels are also being challenged by the energy democracy movement, which is motivated by rising concerns over climate change and other environmental and public health risks, a desire to maintain self-determination at the local level, and the increasing availability and affordability of renewable energy. As these hegemonic structures continue to be dismantled, we anticipate seeing further calls for covenant renewal in neoliberalism and energy in American public rhetoric as those who have benefited from these arrangements attempt to bolster them through discourses of victimhood, exceptionalism, and restoration. Our hope is that future work might examine how and where similar rhetorics of environmental dominance appear across contexts, as well as how they might be resisted.

\section{AUTHOR CONTRIBUTIONS}

JS developed the topical focus for the paper and developed specific analyses and implications. JP provided the theoretical framework and developed specific analyses and implications. Both authors worked closely on revisions. JS prepared the manuscript for final submission. 


\section{ACKNOWLEDGMENTS}

The authors would like to thank the participants and organizers of the 2017 Energy Democracy Symposium, who provided helpful feedback and encouragement on an early draft

\section{REFERENCES}

Abrams, A. (2017). President Trump's Interior Secretary Makes His Staff Raise a Special Flag When He's Around. Time Magazine. Available at: http://time. com/4980898/ryan-zinke-interior-department-flag-ritual-donald-trump/

Adragna, A. (2017). Zinke Took Non-Commercial Flights Too. Politico. Available at: https:/www.politico.com/tipsheets/morning-energy/2017/09/29/zinke-tooknon-commercial-pricey-flights-too-222559

Al-Sibai, N. (2017). Interior Sec. Zinke on Confederate Monument Removal: "Native Indians" Will Want Union Statues Removed Next. Raw Story. Available at: https://www.rawstory.com/2017/10/interior-sec-zinke-on-confederate-monument-removal-native-indians-will-want-union-statues-removed-next/

Alternative Right. (2017). Available at: https://www.splcenter.org/fighting-hate/ extremist-files/ideology/alternative-right

Backus, P. (2017). Zinke Talks Issues at Western Governors' Association Meeting. Independent Record. Available at: http://helenair.com/news/politics/state/ zinke-talks-issues-at-western-governors-association-meeting/article_4c4bcdc5-4098-5906-8ad5-67388351ecd1.html

Beavers, O. (2017). Zinke Shares Beers with Murkowski after Alleged Threats Following Healthcare Vote. The Hill. Available at: http://thehill.com/homenews/ administration/345139-zinke-shares-beers-with-murkowski-after-allegedthreats-over

Bordoff, J. (2017). The American Energy Superpower. Foreign Affairs. Available at: https://www.foreignaffairs.com/articles/united-states/2017-07-06/americanenergy-superpower

Bostdorff, D. M. (2003). George W. Bush's post-September 11 rhetoric of covenant renewal: upholding the faith of the greatest generation. Q. J. Speech 89, 293-319. doi:10.1080/0033563032000160963

Bsumek, P. K., Schneider, J., Schwarze, S., and Peeples, J. (2014). "Corporate ventriloquism: corporate advocacy, the coal industry, and the appropriation of voice," in Voice and Environmental Communication, eds J. Peeples and S. Depoe (New York: Palgrave Macmillan). p. 51-76.

Bump, P. (2017). Why Pence and Trump Keep Framing the NFL Protests as Being About the Military. Washington Post. Available at: https://www.washingtonpost. com/news/politics/wp/2017/10/09/why-pence-and-trump-keep-framing-thenfl-protests-as-being-about-the-military/

Burke, M. J., and Stephens, J. C. (2017). Energy democracy: goals and policy instruments for sociotechnical transitions. Energy Res. Soc. Sci. 33, 35-48. doi:10.1016/j.erss.2017.09.024

Burnett, S. (2017). Trump and the End of Obama's Bitter "War on Coal". The Hill. Available at: http://thehill.com/opinion/energy-environment/353232-trumpand-the-end-of-obamas-bitter-war-on-coal

Chapman, S. (2017). Why Do Whites Oppose the NFL Protests? The Chicago Tribune. Available at: http://www.chicagotribune.com/news/opinion/chap$\mathrm{man} / \mathrm{ct}$-perspec-whites-nfl-anthem-protests-20170927-story.html

Cloud, D. L. (2015). "Civility” as a threat to academic freedom. First Amend. Stud. 49, 13-17. doi:10.1080/21689725.2015.1016359

Coates, T.-N. (2017). The First White President. The Atlantic. Available at: https://www.theatlantic.com/magazine/archive/2017/10/the-first-whitepresident-ta-nehisi-coates/537909/

D’Angelo, C. (2017a). Interior Secretary Orders Protester to "Be Nice" during Visit to Bears Ears. Huffington Post. Available at: https://www.huffingtonpost.com/ entry/ryan-zinke-bears-ears-be-nice_us_59120315e4b05e1ca202516f

D’Angelo, C. (2017b). For a Guy Who Doesn't "Pick Winners," Ryan Zinke Sure Loves Fossil Fuels. Huffington Post. Available at: http://www.huffingtonpost.com/ entry/ryan-zinke-fossil-fuels_us_594befdce4b01cdedf018edd

de Onis, C. (2017). Energy Remix: Decolonial Discourses of Decarbonization. Cambridge, Massachusetts Dissertation, Indiana University.

Denning, L. (2017). Energy Dominance=Flogging Energy. Bloomberg. Available at: https://www.bloomberg.com/gadfly/articles/2017-06-30/trump-s-energydominance-mantra-is-about-flogging-energy of this paper. Peer reviewers also suggested useful revisions that have strengthened the paper. Finally, we would especially like to thank Catalina de Onis for her inspiring work on energy coloniality, which informed how we think about this topic.

Dimaggio, A. (2017). Who Are the "Alt-Right"? On the Rise of Reactionary Hatred and How to Fight It. Counterpunch. Available at: https://www.counterpunch.org/2017/09/22/who-are-the-alt-right-on-the-rise-of-reactionaryhatred-and-how-to-fight-it/

Endres, D. (2009). The rhetoric of nuclear colonialism: rhetorical exclusion of American Indian arguments in the Yucca Mountain nuclear waste siting decision. Commun. Crit. Cult. Stud. 6, 39-60. doi:10.1080/14791420802632103

Endres, D. E., Cozen, B., Barnett, J. T., O’Byrne, M., and Peterson, T. R. (2016). Communicating energy in a climate (of) crisis. Ann. Int. Commun. Assoc. 40, 419-447. doi:10.1080/23808985.2015.11735267

Fears, D., and Eilperin, J. (2017). Zinke Says a Third of Interior's Staff Is Disloyal to Trump and Promises "Huge" Changes. Washington Post. Available at: https:// www.washingtonpost.com/news/energy-environment/wp/2017/09/26/ zinke-says-a-third-of-interiors-staff-is-disloyal-to-trump-and-promises-hugechanges/?utm_term $=0.34 \mathrm{a} 9036 \mathrm{f} 7 \mathrm{f} 23$

Federman, A. (2017). Trump Says He Ended the "War" on Coal Companies. But It's Too Late to Save Them. Washington Post. Available at: https://www. washingtonpost.com/outlook/trump-says-he-ended-the-war-on-coal-companies-but-its-too-late-to-save-them/2017/10/13/52a8f660-a920-11e7-850e2bdd1236be5d_story.html

Fox, J. (1999). Mountaintop removal in West Virginia: an environmental sacrifice zone. Organ. Environ. 12, 163-183. doi:10.1177/1086026699122002

Freemuth, J. (2017). Interior Secretary Zinke Invokes Teddy Roosevelt as Model, but His Public Land Policies Don't. The Conversation. Available at: http://theconversation.com/interior-secretary-zinke-invokes-teddy-roosevelt-as-model-but-his-public-land-policies-dont-84546

Fuller, S., and McCauley, D. (2016). Framing energy justice: perspectives from activism and advocacy. Energy Res. Soc. Sci.11(Suppl. C), 1-8. doi:10.1016/j.erss.2015.08.004

Grandoni, D. (2017). The Energy 202: Zinke Suggests Solar Power May not Best Use of Public Land. Washington Post. Available at: https://www.washingtonpost. com/news/powerpost/paloma/the-energy-202/2017/09/29/the-energy-202zinke-suggests-solar-power-may-not-best-use-of-public-land $/ 59 \mathrm{~cd} 6 \mathrm{a} 0 \mathrm{~d} 30 \mathrm{fb}$ 0468cea81c8a/?utm_term $=0.04$ bcadf2798f

Hecht, G. (2012). Being Nuclear: Africans and the Global Uranium Trade. Cambridge, MA: The MIT Press.

Heffron, R. J., McCauley, D., and Sovacool, B. K. (2015). Resolving society's energy trilemma through the Energy Justice Metric. Energy Policy 87(Suppl. C), 168-176. doi:10.1016/j.enpol.2015.08.033

Hiar, C. (2017). Oil and Gas Execs Top Zinke's Meeting List. E\&E News. Available at: https://www.eenews.net/stories/1060054851

Jasanoff, S., and Kim, S.-H. (2013). Sociotechnical imaginaries and national energy policies. Sci. Cult. 22, 189-196. doi:10.1080/09505431.2013.786990

Kaylor, B. (2013). Earth-a-lujah!: the prophetic environmental discourse of reverend Billy. Environ. Commun. 7, 391-408. doi:10.1080/17524032.2013.791874

Kazin, M. (2016). Trump and American populism: old whine, new bottles. Foreign Aff. 95(6): 17-24.

King, M. (2017a). Aggrieved Whiteness: White Identity Politics and Modern American Racial Formation. Abolition Journal, 1. Available at: https://abolitionjournal. org/aggrieved-whiteness-white-identity-politics-and-modern-american-racial-formation/

King, P. (2017b). Energy Rhetoric Irrelevant in World of \$50 Oil - Analysts. E\&E News. Available at: https://www.eenews.net/stories/1060058364

Klein, N. (2014). This Changes Everything: Capitalism vs. the Climate. New York: Simon \& Schuster.

Kuletz, V. L. (1998). The Tainted Desert: Environmental and Social Ruin in the American West, 1st Edn. New York: Routledge.

Lerner, S. (2010). Sacrifice Zones: The Front Lines of Toxic Chemical Exposure in the United States. Cambridge, MA: MIT Press.

Lipton, E., and Meier, B. (2017). Under Trump, Coal Mining Gets New Life on U.S. Lands. The New York Times. Available at:https://www.nytimes.com/2017/08/06/ us/politics/under-trump-coal-mining-gets-new-life-on-us-lands.html 
López, I. H. (2015). Dog Whistle Politics: How Coded Racial Appeals Have Reinvented Racism and Wrecked the Middle Class. Oxford: Oxford University Press.

Mattson, K. (2009). “What the Heck Are You Up to, Mr. President?” Jimmy Carter, America's "Malaise," and the Speech That Should Have Changed the Country. New York: Bloomsbury.

Mitchell, T. (2013). Carbon Democracy: Political Power in the Age of Oil. London: Verso.

Mufson, S., and Mooney, C. (2017). Trump's Pitch for U.S. "Energy Dominance" Is Dominated by Misleading Claims. Washington Post. Available at: https:// www.washingtonpost.com/news/energy-environment/wp/2017/06/29/thewhite-house-labeled-this-energy-week-and-you-thought-it-was-all-healthcare/?utm_term $=0.667200 \mathrm{e} 2 \mathrm{~b} 926$

Murphy, J. M. (1990). "A time of shame and sorrow": Robert F. Kennedy and the American Jeremiad. Q. J. Speech 76, 401. doi:10.1080/00335639009383933

Oliver, J. E., and Rahn, W. M. (2016). Rise of the Trumpenvolk: populism in the 2016 election. Ann. Am. Acad. Polit. Soc. Sci. 667, 189-206. doi:10.1177/ 0002716216662639

Opie, J., and Elliot, N. (1996). "Tracking the elusive jeremiad," in The Symbolic Earth, 1st Edn, (University Press of Kentucky), 9-37. Available at: http://www. jstor.org/stable/j.ctt130j1tg.4

O'Rourke, D., and Connolly, S. (2003). Just oil? The distribution of environmental and social impacts of oil production and consumption. Annu. Rev. Environ. Resour. 28, 587-617. doi:10.1146/annurev.energy.28.050302.105617

Peeples, J., Bsumek, P., Schwarze, S., and Schneider, J. (2014). Industrial apocalyptic: neoliberalism, coal, and the burlesque frame. Rhetor. Public Aff. 17, 227-253. doi:10.14321/rhetpublaffa.17.2.0227

Pezzullo, P. C. (2009). Toxic Tourism: Rhetorics of Pollution, Travel, and Environmental Justice. Tuscaloosa: The University of Alabama Press.

Plott, E. (2017). Ryan Zinke, Trump's Cowboy Enforcer, Is Ready for His Closeup. GQ. Availableat:https://www.gq.com/story/ryan-zinke-secretary-of-interior-profile

Raimi, D. (2017). Is Energy "Dominance" the Right Goal for US Policy? The Conversation. Available at: https://theconversation.com/is-energy-dominancethe-right-goal-for-us-policy-79825

Rein, L. (2017). Trump's Cabinet Agencies Still Understaffed Despite Flurry of Senate Confirmations. Chicago Tribune. Available at: http://www.chicagotribune. $\mathrm{com} /$ news/nationworld/politics/ct-trump-nominees-senate-confirmations-20170804-story.html

Rein, L., and Harwell, D. (2017). Watchdog Says Interior Secretary Ryan Zinke Failed to Properly Document Travel. Washington Post. Available at: https://www. washingtonpost.com/politics/watchdog-says-interior-secretary-ryan-zinke-failed-to-properly-document-travel/2017/11/16/3277bac6-ca3f-11e7-b0cf7689a9f2d84e_story.html?utm_term $=0.65 \mathrm{e} 53195 \mathrm{a} 6 \mathrm{ff}$

Reinig, L., and Sprain, L. (2016). "Cultural discourses of public engagement: insights for energy system transformation," in Confronting the Challenges of Public Participation: Issues in Environmental, Planning, and Health DecisionMaking. Proceedings of a Symposium at Iowa State University, ed. J. Goodwin (Ames, IA: Science Communication Project).

Republican Platform. (2017). We Believe in America. Available at: https://gop.com/ platform/

Rosteck, T., and Frentz, T. (2009). Myth and multiple readings in environmental rhetoric: the case of an inconvenient truth. Q. J. Speech 95, 1-19. doi:10.1080/00335630802621086

Rubin, J. (2017). The "Golden Past" Is a Crock. Washington Post. Available at: https:// www.washingtonpost.com/blogs/right-turn/wp/2017/11/02/the-golden-pastis-a-crock/

Rucker, P., and Costa, R. (2017). Bannon Vows a Daily Fight for "Deconstruction of the Administrative State". Washington Post. Available at: https://www. washingtonpost.com/politics/top-wh-strategist-vows-a-daily-fight-for-deconstruction-of-the-administrative-state/2017/02/23/03f6b8da-f9ea-11e6-bf01d47f8cf9b643_story.html

Salvador, M., and Norton, T. (2011). The flood myth in the age of global climate change. Environ. Commun. 5, 45-61. doi:10.1080/17524032.2010.544749

Schneider, J., Schwarze, S., Bsumek, P., and Peeples, J. (2016). Under Pressure: Coal Industry Rhetoric and Neoliberalism. London: Palgrave Macmillan.

Scott, R. (2010). Removing Mountains: Extracting Nature and Identity in the Appalachian Coalfields. Minneapolis: University of Minnesota Press.
Shogren, E. (2017). What Drove an Interior Whistleblower to Dissent? High Country News. Available at: http://www.hcn.org/articles/department-of-the-interior-whats-driving-interior-whistleblower-joel-clement-to-dissent-ryan-zinke

Sillars, M. O. (1980). The American jeremiad. Philos. Rhetor. 13, 289-291.

Singer, R. (2010). Neoliberal style, the American re-generation, and ecological jeremiad in Thomas Friedman's "code green". Environ. Commun. 4, 135-151. doi:10.1080/17524031003775646

Thompson, J. (2017). Coal. Guns. Freedom? High Country News. Available at: http://www.hcn.org/articles/coal-how-the-trump-administration-has-seizedmythologies-around-coal

Tidwell, A. S. D., and Smith, J. M. (2015). Morals, materials, and technoscience: the energy security imaginary in the United States. Sci. Technol. Hum. Values 40, 687-711. doi:10.1177/0162243915577632

Wilson, J. (2017). Take a Knee: How Conservative Media Is Reacting to NFL Protesters. The Guardian. Available at: http://www.theguardian.com/us-news/2017/ sep/25/take-a-knee-how-conservative-media-is-reacting-to-nfl-protestors

Wolfe, D. (2008). The ecological jeremiad, the American myth, and the vivid force of color in Dr. Seuss's the Lorax. Environ. Commun. 2, 3-24. doi:10.1080/17524030801936707

Woods, E. D. (2017). Ryan Zinke Is Trump's Attack Dog on the Environment. Outside Magazine. Available at: https://www.outsideonline.com/2266216/ man-flies-his-own-flag

The Associated Press. (2017). Interior Secretary Ryan Zinke Pledges to Streamline Oil and Gas Permits. Denver Post. Available at: http://www.denverpost. com/2017/07/06/ryan-zinke-interior-oil-gas-permits-quicker/ (accessed September 22, 2017)

The White House. (2017). President Trump Vows to Usher in Golden Era of American Energy Dominance. Available at: https://www.whitehouse.gov/ blog/2017/06/30/president-trump-vows-usher-golden-era-american-energy-dominance (accessed October 23, 2017).

Zinke, R. (2017). A Visionfor American EnergyDominance. The Heritage Foundation. Availableat:http://www.heritage.org/event/vision-american-energydominance

Soundcloud. (2017a). Secretaries Ryan Zinke and Sonny Perdue Speak at Boise State University. Available at: https://soundcloud.com/boise-state-university/ secretaries-ryan-zinke-and-sonny-perdue-speak-at-boise-state-university (accessed November 12, 2017).

U.S. Department of the Interior. (2017b). Secretary Zinke Signs Order to Jump-Start Alaskan Energy. U.S. Department of the Interior. Available at: https://www. doi.gov/pressreleases/secretary-zinke-signs-order-jump-start-alaskan-energy (accessed November 10, 2017).

U.S. Department of the Interior. (2017c). Secretary Zinke Statement in Support of President Trump's American Energy Executive Order. U.S. Department of the Interior. Available at: https://www.doi.gov/pressreleases/secretary-zinke-statement-support-president-trumps-american-energy-executive-order (accessed November 12, 2017).

The Associated Press. (2017d). Zinke: One-Third of Interior Employees Not Loyal to Trump. Associated Press. Available at: https://apnews.com/570c910d21be41869f$76 \mathrm{~d} 45 \mathrm{a} 2 \mathrm{c} 55 \mathrm{c} 359$ (accessed November 12, 2017).

U.S. Department of the Interior. (2017e). Zinke Signs Secretarial Order to Streamline Process for Federal Onshore Oil and Gas Leasing Permits. U.S. Department of the Interior. Available at:https://www.doi.gov/pressreleases/zinke-signs-secretarial-order-streamline-process-federal-onshore-oil-and-gas-leasing (accessed November 12, 2017).

Conflict of Interest Statement: This work was not carried out in the presence of any personal, professional, or financial relationships that could potentially be construed as conflicts of interest.

Copyright $\odot 2018$ Schneider and Peeples. This is an open-access article distributed under the terms of the Creative Commons Attribution License (CC BY). The use, distribution or reproduction in other forums is permitted, provided the original author(s) and the copyright owner are credited and that the original publication in this journal is cited, in accordance with accepted academic practice. No use, distribution or reproduction is permitted which does not comply with these terms. 